Volume 2 Nomor. 2, Oktober 2017

P -ISSN : 2541-1179, E-ISSN : 2581-1711

OJS :http://journal.uin-alauddin.ac.id/index.php/instek/index

\title{
ALAT TERAPI VITILIGO DENGAN ULTRA VIOLET- B BERBASIS MIKROKONTROLLER ARDUINO
}

\author{
Usman Umar \\ Dosen Jurusan Teknik Elektro \\ Akademi Teknik Elektromedik Muhammadiyah Makassar \\ Email : Usmanmr4@gmail.com
}

\begin{abstract}
ABSTRAK
Vitiligo adalah penyakit kulit didapat yang ditandai dengan lesi putih yang tidak berpigmen di kulit karena kehilangan fungsi dari melanosit. Prevalensi vitiligo cukup tinggi, yaitu berkisar antara $0.1-2 \%$ dari seluruh penduduk dunia. Penyakit juga dapat terjadi sejak lahir sampai usia lanjut dengan frekuensi tertinggi $(50 \%$ dari kasus) pada usia 10-30 tahun. Terapi vitiligo sendiri sampai saat ini masih kurang memuaskan. Tabir surya dan kosmetik covermask bisa menjadi pilihan terapi yang murah dan mudah serta dapat digunakan oleh pasien sendiri dibanding dengan terapi lainnya,Tujuan penelitian ini sebagai pengembangan teknologi tepat guna dengan menggunakan sistem automatisasi dan pengembangan teknologi kesehatan khsusnya dibidang terapi kesehatan dengan membuat sebuah alat terapi vitiligo dengan menggunakan lampu UVB sebagai media terapi dan melakukan evaluasi dampak penggunaan sinar UVB pada penderita vitiligo. Metodologi penelitian ini melakukan study literatur, dan merancang alat terapi Vitiligo menggunakan Ultra Violet B (UVB) yang dapat bekerja automatis dengan menggunakan Mikrokontroller Arduino dengan pengaturan waktu sesuai dengan keinginan pengguna Hasil penelitian ini setelah dilakukan pengujian alat tingkat kesalahan alat $1,77 \%$, dan tingkat kepuasan terhapat penggunaan alat pada beberapa pasien menunujkkan hasil yang baik.
\end{abstract}

Kata Kunci. Terapi, Vitiligo, Ultra Violet B, Mikrokontroller Arduino

\section{I.PENDAHULUAN}

Tuntutan akan pelayanan kesehatan yang semakin meninngkat dan kompleks harus didukung dengan pembangunan ilmu pengetahuan dan teknologi kesehatan, dengan berkembangnya ilmu pengetahuan dan teknologi disegala aspek kehidupan dan juga dibidang kesehatan. Saat ini telah banyak alat kesehatan yang mengalami kemajuan pesat dimana hal ini peruntukkan untuk mempermudah dalam menenentukan penyakait dan mengobati penyakit. Selain itu kemajuan tekhnologi bidang kesehatan lebih mengutamakan pada pencegahan terjadinya sakit dengan melakukan perawatan dengan terapi dengan teknologi dibidang kesehatan ini memudahkan bagi paramedis melaksanakan tugas. 
Volume 2 Nomor. 2, Oktober 2017

P-ISSN : 2541-1179, E-ISSN : 2581-1711

OJS :http://journal.uin-alauddin.ac.id/index.php/instek/index

Uraian tersebut mendorong kami untuk membuat peralatan kesehatan dibidang teraphy yang dapat digunakan tidak hanya untuk orang sakit tertentu tetapi juga untuk orang sehat guna mencegah terjadinya penyakit dan bisa dilakukan di mana saja tanpa mengganggu segala aktifitas yang dilakukan oleh masyarakat. Salah satunya dalam bidang kesehatan kulit, dimana kulit juga sering mengalami gangguan atau timbul penyakit. Salah satunya adalah vitiligo

Vitiligo adalah penyakit kulit didapat yang ditandai dengan lesi putih yang tidak berpigmen di kulit karena kehilangan fungsi dari melanosit. Prevalensi vitiligo cukup tinggi, yaitu berkisar antara $0.1-2 \%$ dari seluruh penduduk dunia.

\section{II.METODE PENELITIAN}

Metodologi yang digunakan dalam pengerjaan penelitian ini terbagi menjadi beberapa tahap seperti yang ditunjukkan pada gambar berikut flow chart proses penelitian ppembuatan alat terapi vitiligo :

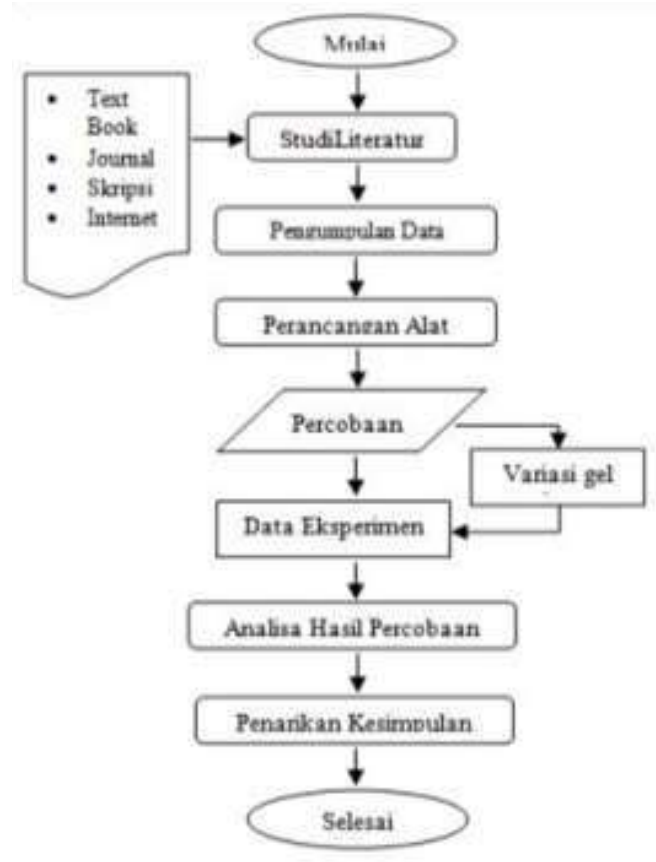

Gambar 1. Flow Chart Penelitian

\section{A. Study Literatur}

Pada tahap ini merupakan tahapan awal dari pengerjaan tugas akhir. Pada tahap ini dilakukan pengumpulan bahan pustaka dan literatur-literatur yang 
Volume 2 Nomor. 2, Oktober 2017

P-ISSN : 2541-1179, E-ISSN : 2581-1711

OJS :http://journal.uin-alauddin.ac.id/index.php/instek/index

INFORIATIKASANS DAN TERNOLOGI

Email : instek@uin-alauddin.ac.id

diperlukan dalam mendukung pengerjaan penelitian ini. Pada pengerjaan penelitian ini literatur pendukung yang digunakan diperoleh dari buku, jurnal, laporan tugas akhir, serta dari internet. Literatur yang diambil dalam tugas akhir ini berkaitan dengan ilmu kesehatan, teknologi elekronika, sistem kontrol dan terapi vitiligo.

\section{B. Pengumpulan Data}

Pada tahap ini dilakukan pengumpulan data-data yang diperlukan untuk merancang serta menganalisa performa sistem kerja alat terapi vitiligo ini dan juga data-data lainnya yang diperlukan. Selain itu pada tahap ini juga dilaksanakan pengumpulan data dengan melakukan eksperimen skala laboratorium untuk mendapatkan data yang dibutuhkan dalam proses perancangan alat.

\section{Kerangka Konsep}

Berikut gambar blok diagram dari Rancang bangun simulasi vitiligo light treatment:

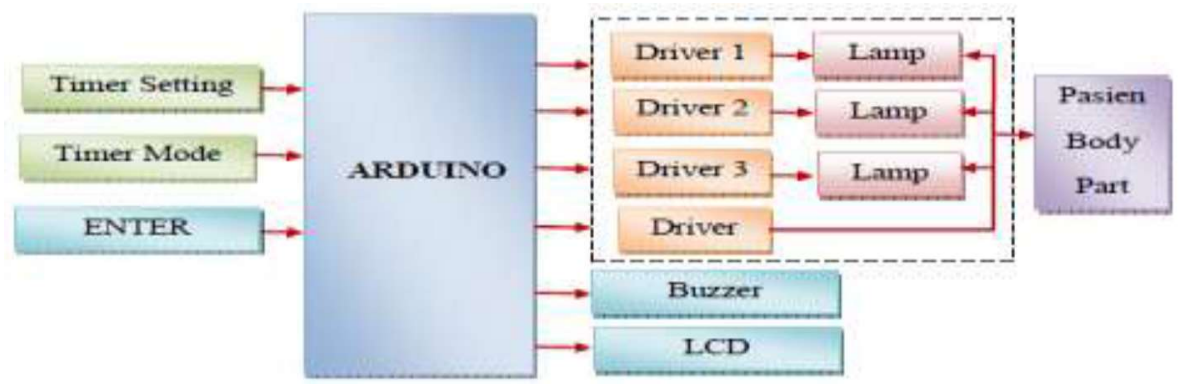

Gambar 2. Blok Diagram Alat Terapi

\section{Perancangan Alat}

Pada tahap ini dilakukan proses perancangan alat yang terdiri dari dua bagian yaitu mekanik dan elektrikal atau sistem kontrol, dari perancangan alat ini dibuat desian alat dan bahan dan peralatan yang digunakan seperti ; lampu UV-B, motor DC, mikroklontroller, relai , kapasitor transformator, LCD, buzzer dan lain lainnya, setelah itu dirancang alat kontrolnya dengan menggunakan mikrokontroller Arduino uno. 
Volume 2 Nomor. 2, Oktober 2017

P-ISSN : 2541-1179, E-ISSN : 2581-1711

OJS :http://journal.uin-alauddin.ac.id/index.php/instek/index

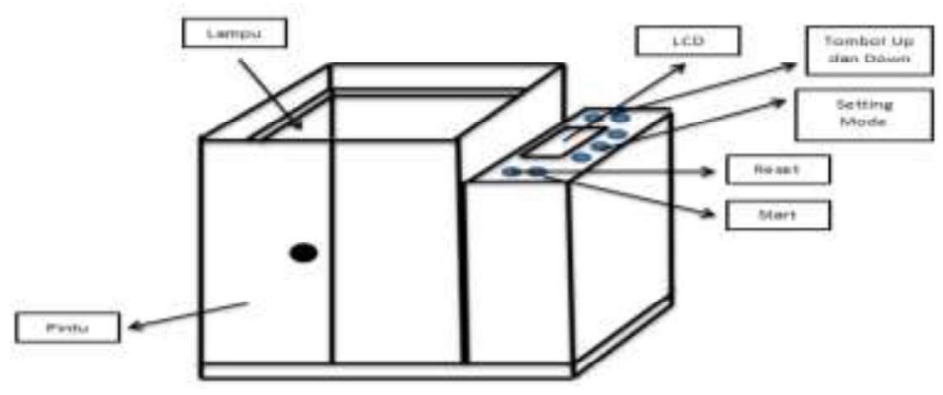

Gambar 3. Desain Alat Keseluruhan

\section{HASIL DAN PEMBAHASAN}

\section{A. Hasil Desain}

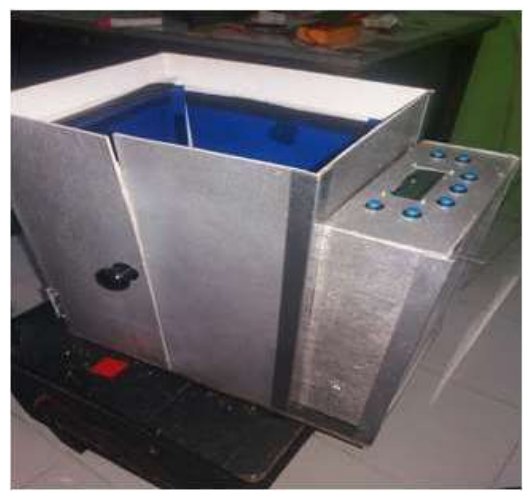

Gambar 4.Alat terapi Vitiligo

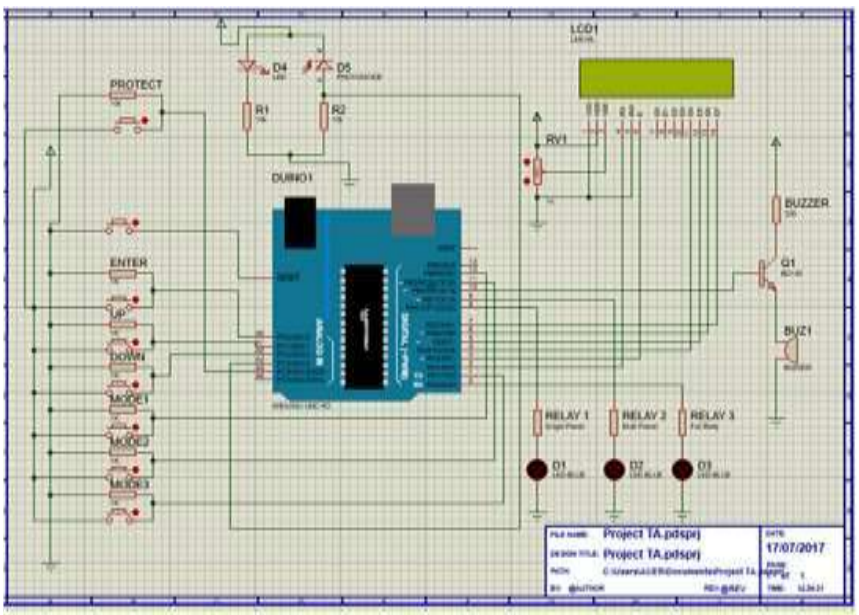

Gambar 5. Hasil Perancangan dengan Arduino 
Volume 2 Nomor. 2, Oktober 2017

P -ISSN : 2541-1179, E-ISSN : 2581-1711

OJS :http://journal.uin-alauddin.ac.id/index.php/instek/index

Email : instek@uin-alauddin.ac.id

\section{B. Hasil Pengujian}

\section{Pengujian dan Pengukuran Modul Alat Terapi}

Setelah membuat modul alat terapi Vitiligo maka perlu dilakukan pengujian dan pengukuran fungsi komponen alat dan program mikrokontroller . Tujuan dari pengukuran dan pengujian adalah untuk mengetahui ketepatan dari pembuatan modul yang penulis lakukan atau untuk memastikan apakah masing-masing bagian (komponen) dari rangkaian modul yang dimaksud telah bekerja sesuai dengan fungsinya seperti yang telah kita rencanakan.

Tabel 1.Hasil pengukuran waktu terapi pada waktu yang disetting 1 menit.

\begin{tabular}{cccc}
\hline $\mathbf{S}$ & $\mathbf{X n}$ & $\mathbf{X n}_{\mathbf{r}} \mathbf{X}_{\text {rata }}$ & $\mathbf{( X n - X r a t a )}^{\mathbf{2}}$ \\
\hline $\mathbf{1}$ & 62 & 1,4 & 1,96 \\
$\mathbf{2}$ & 63 & 2,4 & 5,76 \\
$\mathbf{3}$ & 59 & $-1,6$ & 2,56 \\
$\mathbf{4}$ & 58 & $-2,6$ & 6,76 \\
$\mathbf{5}$ & 61 & 0,4 & 0,16 \\
& 303 & & $\Sigma=2,8$ \\
\hline
\end{tabular}

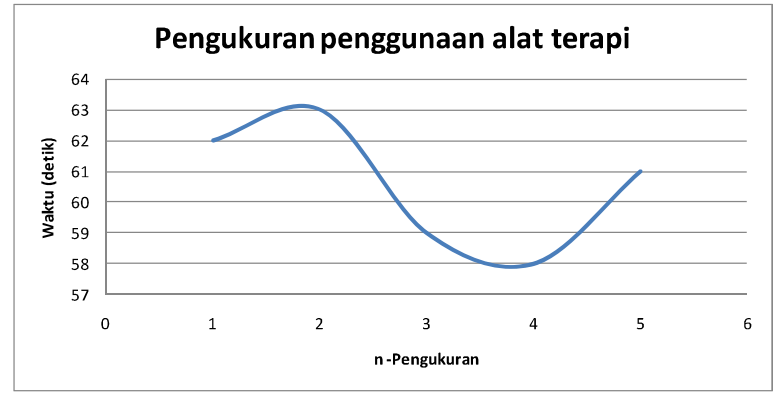

Gambar 6. grafik pengukuran 1 menit

\section{Analisa Perhitungan}

1. Rata Rata (mean)

$$
\begin{gathered}
\text { Rata Rata }(\bar{X})=\frac{\sum X_{n}}{n} \\
(\bar{X})=\frac{302}{5} \\
(\bar{X})=60,6
\end{gathered}
$$


2. Koreksi (k)

$$
\begin{gathered}
k=T_{\text {setting }}-T_{\text {rata rata }} \\
k=60-60,6 \\
k=0,06
\end{gathered}
$$

3. Kesalahan (Error)

4. Simpangan rata-rata (SR)

$$
\begin{gathered}
\text { Error }=\frac{60-60,6}{60} \times 100 \% \\
\text { Error }=-1 \%
\end{gathered}
$$

$$
\begin{gathered}
S R=\frac{\sum X_{n}-\bar{X}}{n} \\
S R=\frac{302-60,6}{302} \\
S R=0,8
\end{gathered}
$$

5. Standart deviasi (SD)

$$
\begin{gathered}
S D=\frac{\sqrt{(X 1-\bar{X})^{2}+\cdots(X n-\bar{X})^{2}}}{n-1} \\
S D=\frac{\sqrt{2,8}}{4} \\
S D=\frac{1,673}{4} \\
S D=0,42
\end{gathered}
$$

6. Ketidakpastian (Ua)

$$
\begin{gathered}
U a=\frac{S D}{\sqrt{n}} \\
U a=\frac{0,42}{\sqrt{5}} \\
U a=\frac{0,42}{2,236} \\
U a=0,188
\end{gathered}
$$

Pengukuran fungsi waktu alat dilakukan dengan variabel waktu antara lain 30 detik, 60 detik , 300 detik. Dari data pengukuran tersebut setelah dilkuan perhitungan dibuat dalam tabel berikut 
Volume 2 Nomor. 2, Oktober 2017

P-ISSN : 2541-1179, E-ISSN : 2581-1711

OJS :http://journal.uin-alauddin.ac.id/index.php/instek/index

Email : instek@uin-alauddin.ac.id

Tabel 2. Hasil Pengukuran dengan variabel setting waktu, 30,60 dan 300 detik

\begin{tabular}{|c|c|c|c|c|c|c|}
\hline \multirow{2}{*}{ No } & Waktu & \multicolumn{5}{|c|}{ Pengukuran $\mathrm{Ke}-n$ pada alat } \\
\hline & ( Detik ) & $\mathrm{X} 1$ & $\mathrm{X} 2$ & X3 & $\mathrm{X} 4$ & $\mathrm{X5}$ \\
\hline \multirow{2}{*}{1} & 30 Detik & \multirow{2}{*}{31} & \multirow{2}{*}{30} & \multirow{2}{*}{31} & \multirow{2}{*}{31} & \multirow{2}{*}{31} \\
\hline & ( 0,5 Menit $)$ & & & & & \\
\hline \multirow{2}{*}{2} & 60 Detik & \multirow{2}{*}{60} & \multirow{2}{*}{61} & \multirow{2}{*}{61} & \multirow{2}{*}{61} & \multirow{2}{*}{61} \\
\hline & ( 1 Menit $)$ & & & & & \\
\hline \multirow{2}{*}{3} & 300 Detik & \multirow{2}{*}{304} & \multirow{2}{*}{304} & \multirow{2}{*}{305} & \multirow{2}{*}{304} & \multirow{2}{*}{303} \\
\hline & ( 5 Menit ) & & & & & \\
\hline
\end{tabular}

Dari hasil pengukuran dan perhitungan bahwa alat Terapi pemijat mata yang menggunakan Mikrokontroler Arduino Uno mempunyai nilai rata -rata dengan variable waktu yang di ukur sebagai berikut :

- $\operatorname{Koreksi}(\mathrm{k})$ : 1,87

- Simpangan rata rata (SR) : 0,99

- Nilai Error : $1,77 \%$

- Standar Deviasi (SD) : 0,267

- Nilai Ketdakpastian (Ua);0,12

Setelah didapat Rata - rata kesalahan maka alat tersebut sesuai dengan Data - data di atas bahwa presentase $<5 \%$. ( kurang dari $5 \%$ ) maka alat tersebut dinyatakan akurat dan dapat digunakan sebagai alat terapi dan sesuai dengan yang di harapkan.

\section{Pengujian Fungsi Alat terapi Pada pasien}

Setelah alat tersebut dilakukan pengujian terhapat fungsi komponen dan modul dan dinyatakan akurat dan dapat difungsikan untuk pengobatan atau terapi pada pasien atau masyarakat dengan menggunakan langsung alat sesuai keingan waktu yang ditentukan oleh pasien sendiri. Pengambilan sampel pengujian pada kelompok usaia yaitu, 7-12 tahun, 13-20 tahun, 21 - 30 tahun, 31 - 45 tahun dan 46 tahun ke atas masing masing 5 orang. 
Volume 2 Nomor. 2, Oktober 2017

P -ISSN : 2541-1179, E-ISSN : 2581-1711

OJS :http://journal.uin-alauddin.ac.id/index.php/instek/index

Email : instek@uin-alauddin.ac.id

Tabel 3. Hasil Pengujian Alat pada pasien

\begin{tabular}{|c|c|c|c|c|}
\hline Kelompok Usia & Jumlah $(\mathrm{X})$ & $\begin{array}{c}\text { Puas } \\
(\mathrm{Y})\end{array}$ & $\begin{array}{c}\text { Tidak Puas } \\
(\mathrm{Z})\end{array}$ & \% kepuasan \\
\hline $7-12$ tahun & 5 & 4 & 1 & $80 \%$ \\
\hline $13-20$ tahun & 5 & 3 & 2 & $60 \%$ \\
\hline $21-30$ tahun & 5 & 4 & 1 & $80 \%$ \\
\hline $31-45$ tahun & 5 & 5 & 1 & $100 \%$ \\
\hline $46<$ tahun & 5 & 4 & 0 & $80 \%$ \\
\hline Total & 25 & 20 & 5 & $400 \%$ \\
\hline Rata rata & 5 & 4 & 1 & $80 \%$ \\
\hline
\end{tabular}

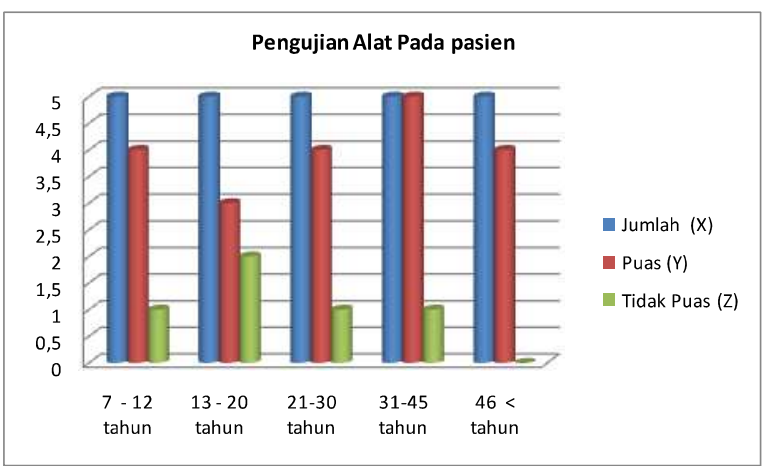

Gambar. 7.Grafik hasil Pengujian alat terapi pada pasien.

Dari data tersebut diatas kepuasan pelanggan terhadap fungsi alat terapi Vitiligo yang dilakukan terapi terhadap 25 orang dan 20 orang mengatakan puas dan 5 orang mengatakan tidak puas sehingga tingkat kepuasan $80 \%$

Tabel 4. Interpertasi hasil penelitian

\begin{tabular}{|c|c|}
\hline Presentase & Interpertasi \\
\hline $0 \%-25 \%$ & Tidak bermanfaat \\
\hline $26 \%-50 \%$ & Kurang bermanfaat \\
\hline $51 \%-75 \%$ & Bermanfaat \\
\hline $76 \%-100 \%$ & Sangat bermanfaat \\
\hline
\end{tabular}

Berdasarkan tabel di atas bahwa hasil pengujian alat pada pasien yang tingkat kepuasan dengan $80 \%$ berarti masuk dalam kelompok sangat bermanfaat. 


\section{IV.KESIMPULAN}

Dari hasil penelitaian, pengukuran dan pengujian alat terapi untuk pemijatan mata dapat disimpulkan bahwa,

1. Fungsi komponen dan program pada Arduino Uno, berfungsi dengan baik dengan rata rata nilai koreksi 1,87 dan error $1,77 \%$ lebih kecil dari 5\% satndar error yang ideal.

2. Alat terapi tersebut mempunyai sistem pembacan waktu yang real time pada monitor LCD sesuai dengan setting waktu, dan jika fungsi lampu UVB telah selesai waktunya akan memberikan informasi melalui suara yang dikeluarkan oleh buzzer.

3. Fungsi alat terapi pada pasien yang dilakukan terhadap 25 orang dengan berbagai usia mulai dari tahun 17 tahun dengan tingkat kepuasan $80 \%$ sehingga nilai tersebut tergolong sangat bermanfaat.

\section{DAFTAR PUSTAKA.}

Alikhan A, Felten LM, Daly M, Petronic Rosic V, (2011), Vitiligo: A Comperhensive Overview Part 1, Introduction Efidemiology, Qulaity of Life, Diagnosis Differential Diagnosis, Association, Histopathology, Etiology and Work Up. J Am Acad Dermatol

Dresbach, Sereana Howard, Wanda Brown. 2008 "Ultraviolet Radiation".. http://ohioline.osu.edu/cd-fact/pdf/0199.pdf..Diakses tanggal 4 Juni 2017

Ezzedine Kh, Boniface. K Diallo .A dkk, 2013, Development and validation of the K-VSCOR for scoring Koebner's phenomenon in vitiligo/non-segmental vitiligo Pigment Cell \& Melanoma Research Volume 26, Issue 3, Pages 402-407 International Federation Of Pigment Cell Societies · Society For Melanoma Research

Fauci, Anthony S., dkk, 2008. Harrison's Principles of Internal Medicine.. United States: Mc.Graw-Hill.

Hapsari, Munira, dkk. 2008, "Fototerapi Narrorband UVB (NB-UVB) pada Vitiligo".. $\quad$ http://jurnal.pdii.lipi.go.id/admin/jurnal/14208103107.pdf. diaksess pada tanggal 5 Juni 2017

Jain, Rita, (2011), Pengobatan Alternative Untuk Mengatasi Tekanan darah, Jakarta Gramedia Pustaka Utama 
Volume 2 Nomor. 2, Oktober 2017

P -ISSN : 2541-1179, E-ISSN : 2581-1711

OJS :http://journal.uin-alauddin.ac.id/index.php/instek/index

Email : instek@uin-alauddin.ac.id

Lotti, Torello, dkk. 2008, Vitiligo: new and emerging treatments. Dermathologic Therapy Volume 21. United States: Blackwell Publishing Inc..

Majid, Imran. 2010, "Vitiligo Management: An Update". British Journal of Medical Practitioner Volume 3..

Matin, Rubeta. 2011 "Vitiligo in Adults and Children". Clinical Evidence.. http://clinicalevidence.bmj.com/ceweb/conditions/skd/1717/1717-get.pdf diakses tanggal 5 Juni 2017

Taieb A, Picardo M. 2008, Epidemiology, definitions and classification. Dalam: Picardo M, Taieb A, Penyunting. Vitiligo. Roma: Springer. 